\title{
Perceptions of a selected group of relatively affluent blacks regarding certain aspects of tourism
}

\author{
C. Boshoff and A.P. du Plessis* \\ Department of Business Economics, Vista University, Private Bag X613, Port Elizabeth, 6000 Republic of South Africa
}

\begin{abstract}
Recent international and local developments have had a negative influence on the South African Tourism industry, particularly regarding the number of overseas tourists visiting the country. To compensate, the industry has renewed its interest in local options - particularly the potential and opportunities the black market offers. However, there appears to be a high degree of uncertainty about utilizing its potential. This study is an attempt to gain some insight into the tourism needs and requirements of a particular market segment, namely relatively affluent blacks. The findings reveal that affluent blacks do not exibit tourism needs which are unique to that particular market segment, but do suggest definite needs and preferences. Information pertaining to these needs is essential for the marketer of tourism to ensure that appropriate marketing strategies are formulated which will allow for proper utilization of opportunities to the advantage of both marketer and consumer.
\end{abstract}

Onlangse internasionale en plaaslike verwikkelinge het, veral wat die aantal oorsese toeriste wat Suid-Afrika besoek betref, 'n negatiewe invloed op die Suid-Afrikaanse toerismebedryf gehad. Om die terugslag te probeer oorkom, het die plaaslike mark opnuut onder die soeklig gekom - veral die geleenthede wat die swart verbruiker bied. Skynbaar bestaan daar egter 'n groot mate van onsekerheid oor hoe daar te werk gegaan moet word om die potensiaal van dié marksegment na behore te benut. Hierdie studie ondersoek die toerismebehoeftes van 'n besondere marksegment, naamlik relatief hoër-inkomste swartes. Die bevindinge toon dat relatief hoër-inkomste swartes nie behoeftes openbaar wat uniek is aan die betrokke marksegment nie. Bepaalde behoeftes en voorkeure kan tog onderskei word. Inligting oor die toerismebehoeftes van swartes is noodsaaklik om die bemarker van toerisme in staat te stel om bemarkingstrategieë te formuleer wat die behoorlike benutting van geleenthede tot voordeel van beide die bemarker en die verbruiker, moontlik sal maak.

- To whom correspondence should be addressed

\section{Introduction}

The South African Tourism industry experienced a 10\% decline in the number of overseas tourists visiting this country during 1985 . Figures for the first few months of 1986 indicate a further $35 \%$ decline (Thomas \& Browning, 1987: 13). Important factors which may have contributed to this decline are media reports about terrorist activities, unrest conditions and economic sanctions imposed on the country.

A possible strategy to overcome the decline in visits by foreign tourists may be to develop the local tourism market. Such a strategy will place the black tourism market under the spotlight. However, there is a high degree of uncertainty over how to utilize the vast potential of this market (Thomas \& Browning, 1987: 15).

\section{Previous research on tourism needs of blacks}

Research on the social and cultural impacts of tourism falls into three different categories (Affeld as quoted by Mathieson \& Wall, 1987: 133) namely the tourist, the host and the tourist-host relationship. Research involving the tourist has stressed the ramifications of the demand for tourist services and the motivations, attitudes and expectations of tourists.

It has been suggested (Green \& Lascaris 1987: 7) that the tourism needs of blacks do not differ significantly from the white market within certain marketing bands (consumer market segments defined in terms of similar levels of education or income). However, growth in demand for holiday travel from the black market has been limited. Four possible reasons have been cited, (Green \& Lascaris, 1987: 6-7) namely:

- the lack of private transport (vehicle ownership);

- relatively low disposable income levels;

- the lack of promotion of holiday facilities; and

- the limited availability of appropriate holiday facilities.

A recent exploratory study to investigate tentative hypotheses about the tourism needs of blacks concluded (Green \& Lascaris, 1987: 7-8): that

$-29 \%$ black adults interviewed took a holiday of more than three nights away in the $\mathbf{1 2}$ months prior to the survey

- the level of income is a key factor influencing holidaying

$-86 \%$ of those who went on holiday stayed with friends and relatives while only $10 \%$ stayed in a hotel

- car ownership is a key determinant in the black holiday business. $51 \%$ of holidaymakers had travelled by car compared with $22 \%$ by train and $25 \%$ by bus.

The above-mentioned research project, using group discussions with upper income group blacks in Soweto, found, inter alia, that:

- blacks have a high level of desire to holiday outside South Africa, particularly African countries and the United States of America.

- in South Africa, coastal areas, particularly Durban and Cape Town, are dominant places which blacks would like to visit.

- black males often mentioned the desire to holiday at game reserves. 
The need for research to establish the tourism needs of blacks is exemplified by the following statement by a black travel agent:

'Regrettably, no research or promotion or advertising has been launched in South Africa to promote black tourism. Most travel agents do not know exactly what the black traveller would like to see and enjoy when in the Cape, Natal or Northern Transvaal, which areas are appealing and are of interest to them. Where do they want to go for a holiday and why?'

(Msomi, 1987: 12).

\section{Objectives}

In discussing market segmentation, Kotler (1984: 252-253) points out that buyers comprising a market differ in one or more respects. They may differ in, for example, wants, resources and geographical locations. Instead of 'customizing' products to satisfy each specific buyer, marketers identify broad classes of buyers who differ in their product requirements and/or marketing responses - so-called market segments. Major segmentation variables for consumer markets are geographic, demographic, psychographic and behavioral (Kotler, 1984: 256). An example of a demographic variable is level of income. This variable is, according to Kotler (1984: 257), a ' $\ldots$ longstanding practice in such product and service categories as automobiles, boats, clothing, cosmetics, and travel'.

Against this background a specific segment of the South African tourism market was selected as focus of this study, (using race and income as segmentation variables) namely relatively affluent blacks.

The reasons why income was chosen as a segmentation variable were based on previous research regarding the tourism needs of blacks (Green \& Lascaris, 1987: 6-8) which concluded that: the level of income is a key factor influencing holidaying, and the growth in demand for holiday travel from the black market was limited for four reasons, one being, relatively low levels of disposable income.

The particular market segment (relatively affluent blacks) was selected as it commands relatively higher discretionary income and as McCarthy \& Perreault (1984: 184) suggest: 'It is common sense that a wealthy family will spend more money than a poor one ...' Furthermore, tourism is a luxury and until recently was restricted to the select few who could afford both the time and the money to travel (Mathieson \& Wall, 1987: 1; Pearce, 1985: 25). Tourism is a particular form of recreational behavior which is influenced by a number of factors including per capita income, purchasing power and disposable income (Mathieson \& Wall, 1987: 17). Available financial resources thus not only appear to have an important influence on tourism in a broad context but a relatively high income market segment offer the marketer of tourism a relatively better opportunity to utilize.

With regard to relatively affluent blacks the specific objectives of this study were to:
- determipe whether they do have a desire to holiday away from home.

- determine how often they holiday away from home.

- establish which places they visit and which mode of transport and accommodation they use.

- establish which places they would prefer to visit and which mode of transport and accommodation they would prefer to use.

- investigate their perceptions of holidaying with whites and their evaluation of holiday facilities available to them.

- establish their general needs pertaining to tourism.

\section{Method}

As the objective was to research the tourism needs of relatively affluent blacks, a non-probability purposive sampling procedure was used where known respondents were asked to nominate others who, from time to time, holiday away from home or who may be able to afford a holiday'. The difficulty of continuously expanding the sample necessitated the determination of a cut-off point (200). For the purpose of the study a minimum gross income level of $\mathbf{R} 600$ per month was set, which resulted in the exclusion of eight questionnaires which did not meet this requirement. The final sample size was thus 192. Respondents were interviewed by trained

Table 1 Demographic characteristics of respondents

\begin{tabular}{|c|c|c|}
\hline \multirow{2}{*}{$\begin{array}{l}\text { Demographic variables } \\
\text { Sex }\end{array}$} & \multicolumn{2}{|c|}{ Number $\%$ of tota } \\
\hline & & \\
\hline Male & 117 & 60,9 \\
\hline \multirow[t]{2}{*}{ Female } & 75 & 39,1 \\
\hline & 192 & 100,0 \\
\hline \multicolumn{3}{|l|}{ Highest educational level } \\
\hline Degree & 49 & 25,5 \\
\hline Diploma & 89 & 46,4 \\
\hline Std 10 & 43 & 22,4 \\
\hline Std 8 & 10 & 5,2 \\
\hline \multirow[t]{2}{*}{ Std 5 and lower } & 1 & 0,5 \\
\hline & 192 & 100,0 \\
\hline \multicolumn{3}{|c|}{ Monthly income level (gross per month) } \\
\hline $600-799$ & 16 & 8,3 \\
\hline $800-999$ & 33 & 17,2 \\
\hline $1000-1199$ & 29 & 15,1 \\
\hline \multirow[t]{2}{*}{$1200+$} & 114 & 59,4 \\
\hline & 192 & 100,0 \\
\hline \multicolumn{3}{|l|}{ Vehicle ownership } \\
\hline Own a vehicle & 125 & 65,1 \\
\hline \multirow[t]{2}{*}{ No vehicle } & 67 & 34,9 \\
\hline & 192 & 100,0 \\
\hline \multicolumn{3}{|l|}{ Age distribution } \\
\hline $21-29$ & 39 & 20,3 \\
\hline $30-39$ & 94 & 49,0 \\
\hline $40-49$ & 34 & 17,7 \\
\hline $50-59$ & 23 & 12,0 \\
\hline \multirow[t]{2}{*}{$60+$} & 2 & 1,0 \\
\hline & 192 & 100,0 \\
\hline
\end{tabular}


fieldworkers and information was recorded on structured questionnaires. Table 1 contains details of the demographic composition of the respondent group.

An analysis of Table 1 indicates that the respondent group consists of relatively affluent blacks $(91,7 \%$ earn more than $\mathrm{R} 800$ per month), who are relatively well qualified $(94,3 \%$ have at least a matric qualification) and the majority $(66,7 \%)$ falls in the age group 30 years to 49 years.

\section{Findings}

Previous holidays

Table 2 reveals that $38,0 \%$ of the respondents went on holiday away from home during the past six months ${ }^{2}$ and a further $27,1 \%$ during the past year. Only $16,1 \%$ of the respondents have not been on holiday for more than two years while $2,1 \%$ have never been on holiday. It thus appears as if the respondents who have the necessary financial means wish to holiday away from home and actually do so.

Table 3 indicates that $51,0 \%$ of the respondents used their own vehicle for transport purposes during their last holiday. Air transport is the second most used mode of transport, having been used by $18,8 \%$ of respondents.

Table 4 shows that the majority of the respondents did not make use of commercial accommodation on their previous holiday. Relatives provided accommodation to $35,9 \%$ of the respondents while $27,1 \%$ stayed with friends. Of the five grades of hotels available, 5-star hotels proved to be the most popular, being patronized by $13,5 \%$ of the respondents on their last holiday.

Table 2 Time period elapsed since previous holiday away from home

\begin{tabular}{lrr}
\hline Time period & Number $\%$ of total \\
\hline During the last six months & 73 & 38,0 \\
During the past year & 52 & 27,1 \\
During the past two years & 31 & 16,1 \\
Have not been on holiday for more than two years & 32 & 16,7 \\
Never & 4 & 2,1 \\
Total & 192 & 100,0 \\
\hline
\end{tabular}

Table 3 Mode of transport used during previous holiday

\begin{tabular}{lrr}
\hline Mode of transport & Number \% of total \\
\hline Own vehicle & 98 & 51,0 \\
Aeroplane & 36 & 18,8 \\
Bus & 16 & 8,3 \\
Train & 16 & 8,3 \\
Taxi & 14 & 7,3 \\
Other & 8 & 4,2 \\
Not applicable & 4 & 2,1 \\
Total & 192 & 100,0 \\
\hline
\end{tabular}

Table 4 Type of accommodation used on last holiday away from home

\begin{tabular}{lrr}
\hline Accommodation & \multicolumn{2}{c}{ Number $\%$ of total } \\
\hline Relatives & 69 & 35,9 \\
Friends & 52 & 27,1 \\
1-star hotel & 3 & 1,6 \\
2-star hotel & 6 & 3,1 \\
3-star hotel & 15 & 7,8 \\
4-star hotel & 3 & 1,6 \\
5-star hotel & 26 & 13,5 \\
Caravan & 4 & 2,1 \\
Holiday cottage & 4 & 2,1 \\
Not applicable & 4 & 2,1 \\
Other & 5 & 2,6 \\
No response & 1 & 0,5 \\
Total & 192 & 100,0 \\
\hline
\end{tabular}

\section{Selected tourism preferences}

Respondents were asked to indicate their preferences with regard to mode of transport used when on holiday, holiday locations in South Africa and their choice between seaside or inland resorts. Table 5 reveals that $51,6 \%$ of the respondents would prefer to use their own vehicle when on holiday and $32,8 \%$ would prefer to make use of air transport. Almost half of the respondents $(46,4 \%)$ indicated that they preferred a seaside resort, $15,6 \%$ preferred an inland or country resort and $35,9 \%$ said they had no particular preference (no response $2,1 \%$ )

Table 6 provides an exposition of responses when respondents were asked where in South Africa they would prefer to spend a 'dream holiday'.

Table 6 reveals that $35,4 \%$ of the respondents prefer Durban as location for a 'dream holiday' while $18,8 \%$ prefer Cape Town and $18,2 \%$ Sun City. If it is taken into account that $46,4 \%$ prefer seaside resorts as holiday locations in general and $54,2 \%$ prefer either Durban or Cape Town as locations for a 'dream holiday' it appears as if the respondents have a definite preference for a sea or coastal environment for holidaying purposes.

\section{Table 5 Preferred mode of transport when on holiday}

\begin{tabular}{lrr}
\hline Mode of transport & \multicolumn{2}{c}{ Number $\%$ of total } \\
\hline Own vehicle & 99 & 51,6 \\
Aeroplane & 63 & 32,8 \\
Train & 12 & 6,2 \\
Boat & 8 & 4,2 \\
Bus & 5 & 2,6 \\
Taxi & 3 & 1,6 \\
Other & 2 & 1,0 \\
Total & 192 & 100,0 \\
\hline
\end{tabular}


Table 6 Locations preferred for a 'dream holiday'

\begin{tabular}{lrr}
\hline Durban & 68 & 35,4 \\
Cape Town & 36 & 18,8 \\
Sun City & 35 & 18,2 \\
Johannesburg & 10 & 5,2 \\
Wild Coast & 7 & 3,8 \\
Mpekweni Holiday Resort & 5 & 2,6 \\
Plettenberg Bay & 3 & 1,6 \\
Bloemfontein & 2 & 1,0 \\
Bophutatswana & 2 & 1,0 \\
Amatola Sun (Ciskei) & 2 & 1,0 \\
Hoggsback & 2 & 1,0 \\
Game Reserve & 2 & 1,0 \\
Others & 9 & 4,7 \\
No response & 9 & 4,7 \\
Total & 192 & 100,0 \\
\hline
\end{tabular}

Table 7 Evaluation of holiday facilities available to blacks only

\begin{tabular}{lrc}
\hline Evaluation rating & \multicolumn{2}{c}{ Number \% of total } \\
\hline Excellent & 0 & 0 \\
Adequate & 7 & 3,7 \\
Inadequate & 58 & 30,3 \\
Poor & 102 & 53,0 \\
Do not know & 24 & 12,5 \\
No response & 1 & 0,5 \\
Total & 192 & 100,0 \\
\hline
\end{tabular}

Table 8 Evaluation of holiday facilities open to all races

\begin{tabular}{lrr}
\hline Evaluation rating & \multicolumn{2}{c}{ Number \% of total } \\
\hline Excellent & 34 & 17,7 \\
Adequate & 80 & 41,7 \\
Inadequate & 42 & 21,9 \\
Poor & 8 & 4,2 \\
Do not know & 26 & 13,5 \\
No response & 2 & 1,0 \\
Total & 192 & 100,0 \\
\hline
\end{tabular}

\section{Respondents' evaluation of available holiday facilities}

Respondents were requested to express their opinion with regard to the adequacy of holiday facilities that are presently available to blacks only. Table 7 shows that $53 \%$ of respondents rate holiday facilities available to blacks only as poor, while $30,3 \%$ rate them as inadequate. Only $3,7 \%$ are of the opinion that they are adequate while not one regards them as excellent.

Respondents were also requested to express their opinion regarding holiday facilities that are open to all race groups. Table 8 shows that the majority of the respondents feel these facilities are excellent $(17,7 \%)$ or adequate $(41,7 \%)$. Only $21,9 \%$ feel holiday facilities open to all races are inadequate while $4,2 \%$ rate them as poor.

Respondents' attitude towards holidaying with whites

Respondents were asked to descrire their attitude towards holidaying with whites. Table 9 reveals that the majority of respondents either do not mind $(71,9 \%)$ or prefer $(12,0 \%)$ holidaying with whites while only $7,8 \%$ try to avoid it or refuse to holiday with whites $(7,8 \%)$.

An attempt was made to establish respondents' views with regard to whites' attitude towards holidaying with blacks. For this purpose the question was duplicated attitude of the younger generation of whites and the older generation of whites. The responses, with regard to the younger generation of whites are tabulated in Table 10 and reveal that $19,3 \%$ of the respondents think younger whites prefer to holiday with blacks while $46,3 \%$ are of the opinion younger whites do not mind. Only $17,2 \%$ think younger whites try to avoid holidaying with blacks while only $10,4 \%$ think they refuse to holiday with blacks.

Table 9 Attitude towards holidaying with whites

\begin{tabular}{lrr}
\hline Variable & Number \% of total \\
\hline Prefer it & 23 & 12,0 \\
Do not mind & 138 & 71,9 \\
Try to avoid it & 15 & 7,8 \\
Refuse to holiday with whites & 15 & 7,8 \\
No response & 1 & 0,5 \\
Total & 192 & 100,0 \\
\hline
\end{tabular}

Table 10 Respondents' view of young whites' attitudes towards holidaying with blacks

\begin{tabular}{lrr}
\hline Attitude & \multicolumn{2}{c}{ Number \% of total } \\
\hline Prefer it & 37 & 19,3 \\
Do not mind & 89 & 46,3 \\
Try to avoid it & 33 & 17,2 \\
Refuse to holiday with blacks & 20 & 10,4 \\
No response & 13 & 6,8 \\
Total & 192 & 100,0
\end{tabular}

Table 11 Respondents' view of older whites' attitude towards holidaying with blacks

\begin{tabular}{lrr}
\hline Attitude & \multicolumn{2}{c}{ Number $\%$ of total } \\
\hline Prefer it & 5 & 2,6 \\
Do not mind & 12 & 6,3 \\
Try to avoid it & 66 & 34,3 \\
Refuse to holiday with blacks & 101 & 52,6 \\
No response & 8 & 4,2 \\
Total & 192 & 100,0 \\
\hline
\end{tabular}


The responses to a further question, pertaining to the attitude of the older white generation, are shown in Table 11, which indicates a contrasting picture to Table 10. Only $2,6 \%$ of the respondents feel that older whites prefer to holiday with blacks while only $6,3 \%$ think they do not mind. The majority of respondents feel that older whites try to avoid holidaying with blacks $(34,3 \%)$ or refuse to holiday with blacks $(52,6 \%)$.

Importance of various holiday resort facilities, attractions or activities

To gain further insight into the tourism and holiday needs and requirements of blacks, respondents were asked to rate the importance of a number of holiday resort attractions, facilities and activities. The evaluations are tabulated in Table 12 and show that seeing places of interest (sightseeing), meeting people, live music performances, picnic facilities, sports facilities and movie, television and video facilities are particularly important to respondents. The least important are scuba diving facilities, hunting, fishing, hiking and bar facilities.

\section{Summary}

The objective of this study was not to analyze the total tourism market, but only a particular segment, namely relatively affluent blacks. The most important findings regarding the respondent group, selected from this segment are:

- that respondents have a definite desire to holiday away from home and actually do so regularly;

- on their previous holiday almost half of the respondents used their own vehicle for transport purposes and the majority did not make use of available commercial accommodation;

- that when the respondents go on holiday they would prefer to use their own vehicle $(51,6 \%)$ or air transport $(32,8 \%)$;

- that the majority of the respondents would prefer to spend a so-called 'dream holiday' in Durban $(35,4 \%)$, Cape Town $(18,8 \%)$ or Sun City $(18,2 \%)$;

- holiday facilities available to blacks only are rated as poor by $53 \%$ of respondents and as inadequate by $30,3 \%$;

- holiday facilities open to all races are rated as excellent by $17,7 \%$ of the respondents and as adequate by $41,7 \%$;

- the majority of the respondents either prefer $(12,0 \%)$ or do not mind $(71,9 \%)$ holidaying with whites;

- younger whites prefer to holiday with blacks according to $19,3 \%$ of respondents while $46,3 \%$ feel younger whites do not mind;

Table 12 Relative importance ratings of various holiday attractions/ facilities*

\begin{tabular}{|c|c|c|c|c|}
\hline \multirow[b]{2}{*}{$\begin{array}{l}\text { Attractions/ } \\
\text { facilities }\end{array}$} & \multicolumn{4}{|c|}{ Rating } \\
\hline & Important & Indifferent & $\begin{array}{c}\text { Not } \\
\text { Important }\end{array}$ & $\begin{array}{c}\text { No } \\
\text { Response }\end{array}$ \\
\hline Swimming pool & 103 & 35 & 50 & 4 \\
\hline Beach & 155 & 21 & 14 & 2 \\
\hline Bar facilities & 47 & 41 & 100 & 4 \\
\hline Movies, T.V., video & 144 & 34 & 13 & 1 \\
\hline Sports facilities & 143 & 31 & 15 & 3 \\
\hline Picnic facilities & 146 & 27 & 19 & $\mathbf{0}$ \\
\hline Dancing, disco & 80 & 55 & 51 & 6 \\
\hline Theatre & 125 & 45 & 17 & 5 \\
\hline Live music performance & 158 & 27 & 6 & 1 \\
\hline Tranquil (quiet) atmosphere & 74 & 66 & 50 & 2 \\
\hline Shady trees, green grass & 118 & 41 & 31 & 2 \\
\hline Meeting people & 159 & 24 & 9 & 0 \\
\hline Seeing places of interest & 181 & 4 & 6 & 1 \\
\hline Visiting museums, monuments & 131 & 37 & 22 & 2 \\
\hline \multicolumn{5}{|c|}{ Observing life styles, customs of other } \\
\hline population groups & 133 & 40 & 18 & 1 \\
\hline Exploring nature & 104 & 46 & 33 & 9 \\
\hline Hiking & 20 & 53 & 117 & 2 \\
\hline Casino, gambling & 80 & 47 & 64 & 1 \\
\hline Fishing & 18 & 34 & 140 & $\mathbf{0}$ \\
\hline Hunting & 16 & 29 & 144 & 3 \\
\hline Scuba diving & 9 & 25 & 154 & 4 \\
\hline
\end{tabular}

- Some of these attractions/facilities may overlap, but the intention was to make the choices as wide as possible 
- the majority of the respondents feel that older generation whites try to avoid holidaying with blacks $(34,3 \%)$ or refuse to holiday with blacks $(52,6 \%)$;

- important holiday resort facilities, attractions or activities to respondents include seeing places of interest (sightseeing), meeting people, live music performances, picnic and sports facilities and movie, television and video facilities.

\section{Limitentione of thie study}

The limitations of this study are:

- The sample size was only 192.

- A non-probability sample was used and no sophisticated statistical analysis was attempted.

- The sample resided in a limited geographical area which could have influenced the nature of responses.

- Not all tourism needs and requirements could be addressed.

\section{Concluaion}

The findings of this study point to specific tourism needs and requirements of relatively affluent blacks.

Although not specifically tested, the findings do not prove the theory wrong that the black tourism market does not differ significantly from the white market within certain marketing bands (market segments defined in terms of levels of education and income), as suggested by Green \& Lascaris (1987: 7).

This study provides some important pointers to guide further researeh on the tourism needs of blacks, particularly in relation to the white market, to establish whether significant differences exist. Such information will aid the marketer of tourism in segmenting the tourism market which will facilitate the formulation of effective marketing mix strategies, particularly the communication strategy.

\section{Notes}

1. Throughout this article the concept 'holiday' will imply a holiday away from home.

2. This survey was conducted during August 1987.

\section{Roferences}

Green, N. \& Lascaris, R. 1987. The Changing Face of the South African Consumer. S. Afr. Tourism Rev., vol. 1, October, 4-8.

Kotler, P. 1984. Marketing Management : Analysis, Planning and Control. Englewood Cliffs, New Jersey: McGraw-Hill, $794 \mathrm{p}$.

Mathieson, A. \& Wall, G. 1987. Tourism: Economic, physical and social impacts. Essex, England: Longman Group, $208 \mathrm{p}$.

McCarthy, E.J. \& Perreault, W.D. 1984. Basic Marketing. 8th Edition. United States of America : Richard D. Irwin, $841 \mathrm{p}$.

Msomi, M.D. 1987. The Black Travel Agent. S. Afr. Tourism Rev., vol. 1, October, 11-13.

Pearce, D. 1985. Tourist Development. Essex, England: Longman Group, 112 p.

Thomas, S. \& Browning, P. 1987. The Tourism Resources of Southern Africa. S. Afr. Tourism Rev., vol. 1, February, 6-16. 